\title{
ASPEK-ASPEK PEMBENTUK KUALITAS TEMPAT BERDASARKAN SURVEI KAPABILITAS: DETERMINAN BAGI KEBAHAGIAAN MASYARAKAT
}

\author{
Place's Quality Determinant for People Happiness Based on \\ Capability Survey
}

RWD Pramono ${ }^{1}$, Ishmah Aditia Nurfajrina ${ }^{2}$, and Nastity Nariswari ${ }^{3}$

Diterima: 16 Juni 2018 Disetujui: 3 Desember 2018

\begin{abstract}
Abstrak: Kebahagiaan dapat menjadi indikator penghubung pembangunan berkelanjutan dengan orientasi peningkatan kualitas hidup masyarakat. Salah satu penentu kebahagiaan adalah kualitas tempat. Dalam penelitian ini, kualitas tempat didefiniskan berdasarkan analisis terhadap rekaman persepsi dan pengalaman hidup masyarakat. Penelitian dilakukan berdasar pendekatan kapabilitas (PK) yang dijabarkan menjadi kerangka survei berupa kuisioner, beberapa pertanyan tambahan terkait dengan evaluasi diri terhadap tingkat kebahagiaan, serta pertanyaan yang menuntun responden untuk mengobservasi lingkungan tempat tinggal atau kotanya. Data persepsi responden dianalisis korelasinya yang dilanjutkan dengan analisis faktor untuk mengidentifikasi aspek-aspek pembentuk kualitas tempat. Pembahasan terhadap hasil temuan menjelaskan bagaimana suatu tempat dapat berkontribusi terhadap peningkatan kebahagiaan serta apa saja elemen fisik yang paling menentukan.
\end{abstract}

Keyword in Bahasa: aset, kapabilitas, kebahagiaan, kualitas tempat

\begin{abstract}
Happiness can be an indicator of connecting sustainable development with an orientation to improve the community's quality of life. The quality of place becomes one determinants of this happiness. This study defined the quality of place based on an analysis of people's perceptions and life experiences. The study was conducted with the capability approach (CA) which was translated into a survey framework in questionnaires, some additional questions related to self-evaluation of the happiness level, as well as questions that led respondents to observe the environment in their neighbourhood area and its city. The perceptions data were analyzed in correlation, followed by factor analysis to identify the quality of the place parameters. The findings explains how a place can contribute to increased happiness and what are the most decisive physical elements.
\end{abstract}

Keywords: asset, capabilitas, happiness, quality of place

\section{PENDAHULUAN}

Kebahagian dapat menjadi penghubung pembangunan berkelanjutan dengan orientasi peningkatan kualitas hidup masyarakat secara langsung (Cloutier S. \& Pfeiffer D., 2017), karenanya kebahagian ditetapkan sebagai salah satu tujuan pokok dari pembangunan (UN-United Nations, 2012). Namun demikian, bagaimana publik dapat

\footnotetext{
${ }^{1}$ Departemen Teknik Arsitektur dan Perencanaan FT UGM, Yogyakarta

${ }^{2}$ Perencanaan Wilayah dan Kota, DTAP FT UGM, Yogyakarta
} 
mencapainya masih menjadi diskusi panjang. Pendekatan Kapabilitas (PK) (Sen, 1999, 2000) berprospek untuk menjadi landasan berpikir untuk tujuan ini. Menurut pendekatan ini, terdapat dua (2) jenis kebebasan yang harus diupayakan untuk mencapai kebahagian dan kesejahteraan, yaitu kebebasan pada level dasar berupa terpenuhinya kebutuhan pokok seperti pangan, sandang, papan, dan kebebasan untuk memilih (freedom to choose) pada level yang lebih tinggi. Kapabilitas sendiri diartikan sebagai besaran peluang seseorang untuk memilih 'functioning', yaitu kemampuan untuk melakukan (to do) berbagai kegiatan atau pilihan menjadi (to be), seperti pilihan profesi, adalah prasyarat bagi masyarakat untuk mencapai kebahagiaan diri.

Kapabilitas ditentukan oleh ketersediaan aset dan secara empirik ditemukan hubungan antara kebahagiaan dengan keberadaan aset yang terklasifikasi menjadi (1) Individual Tangible Asset (ITA), (2) Public Tangible Asset (PTA), (3) Individual Intangible Asset (IIA), (4) Social Institutional Asset (SIA), dan (5) Economic Institutional Asset (EIA) (pramono 2016). Hubungan antar kelompok aset diilustrasikan pada gambar 1. PTA, SIA dan EIA dapat dilelompokkan sebagai aset tempat karena melekat pada tempat.

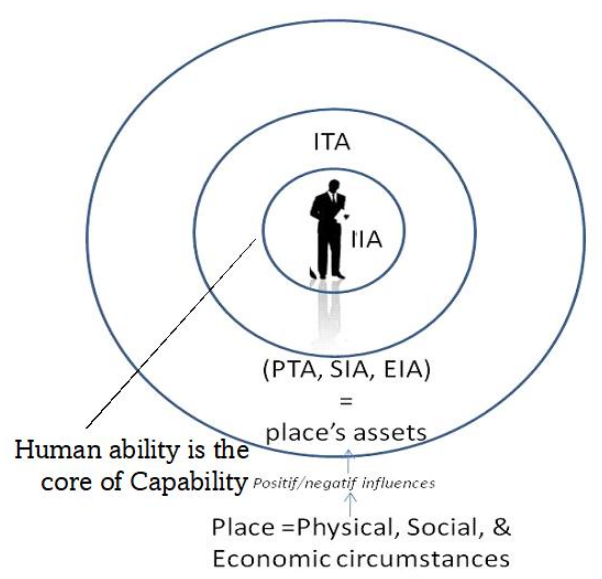

Sumber: (Pramono, R. W. D., 2016)

Gambar 1. Orbit Aset yang Menentukan Kapabilitas Seseorang

Individual Tangible Asset (ITA) dapat menjadi indikator kekayaan seseorang. Aset tempat berpengaruh besar terhadap kapabilitas untuk menghasilkan ITA dan mempermudah proses konsumsi. Aset tempat yang memadai mengurangi biaya pemenuhan kebutuhan, misalnya pengurangan biaya transportasi, biaya kesehatan, ataupun biaya transaksi, dan berpengaruh terhadap kebahagiaan. Temuan ini sejalan dengan konsep "place's attachement" (Scannell \& Gifford, 2017) yang menjelaskan bahwa kebahagiaan adalah sebagai manfaat psikologis dari lingkungan hidup/sistem tatanan tempat manusia karenanya, kualitas aset tempat harus menjadi area kajian dan prioritas perencanaan (Fleury-Bahi, Pol, \& Navarro, 2017).

\section{METODE}

Penelitian terkait kualitas tempat sebagai keuntungan subjektif seseorang dari kondisi objektif-terukur atribut tempat dapat dilakukan dengan pendekatan obyektif (atau eksogen) berdasar indikator observable-terukur (Ira V., 2003; Rogerson, et.al, 1989; van 
Kamp, et.al, 2003) atau berdasarkan indikator subjektif yang diungapkan responden (pendekatan endogen). Kedua pendekatan dapat saling (Heř manová, E., 2012).

Penelitian kali ini menggunakan kerangka kerja survei untuk mengevaluasi variabel aset dari persepsi responden yang ditemukan (Pramono, R. W. D. \& Woltjer, J., 2011). Inti dari kerangka kerja ini adalah evaluasi aset secara perseptual oleh masyarakat terhadap kondisi diri dan lingkungan tempat mereka hidup. Alat evaluasi berupa kuisioner mencakup 40 komponen aset fisik maupun non fisik, yang tidak semuanya langsung melekat pada tempat. Dalam kerangka kerja survei ini, masyarakat yang terpilih sebagai responden diminta untuk mengisi kusioner yang telah disediakan (Tabel 1.). Keseluruhan jenis aset dapat dilihat pada tabel 10. Responden dipilih secara multistage random sampling dari enam (6) desa yang dipilih secara purposif untuk merepresentasikan tipologi tempat berdasarkan perbedaan tingkat kekotaannya. Karakteristik desa sampel dapat dilihat pada tabel 2.

Tabel 1. Questionnaires Design as Capability Survey Tools

\begin{tabular}{|c|c|c|c|c|c|c|c|c|c|c|}
\hline \multirow[b]{2}{*}{ No } & \multirow[b]{2}{*}{$\begin{array}{c}\text { Components/ } \\
\text { Assets }\end{array}$} & \multicolumn{9}{|c|}{ Availability } \\
\hline & & Better & $\begin{array}{c}\text { Not so } \\
\text { Much } \\
\text { Different } \\
\text { to } \\
\text { Previous/ } \\
\text { No } \\
\text { Improve } \\
\text { ment }\end{array}$ & $\begin{array}{c}\text { No } \\
\text { Exist/Not } \\
\text { Accessible/ } \\
\text { Unclear/ } \\
\text { Influences }\end{array}$ & $\begin{array}{c}\text { Wor } \\
\text { se }\end{array}$ & $\begin{array}{l}\text { Very } \\
\text { Help- } \\
\text { full }\end{array}$ & $\begin{array}{l}\text { Help- } \\
\text { full }\end{array}$ & $\begin{array}{c}\text { Unclear } \\
\text { Influenc } \\
\text { es }\end{array}$ & $\begin{array}{l}\text { Con- } \\
\text { straini } \\
\text { ng }\end{array}$ & $\begin{array}{l}\text { Very } \\
\text { Con- } \\
\text { strain } \\
\text { ing }\end{array}$ \\
\hline (1) & (2) & (3) & (4) & (5) & (6) & (7) & (8) & (9) & (10) & (11) \\
\hline 1 & $\begin{array}{l}\text { Score } \\
\text { Space/ } \\
\text { land to reside }\end{array}$ & 2 & 1 & 0 & -2 & 2 & 1 & 0 & -1 & -2 \\
\hline 2 & $\begin{array}{l}\text { Space/land for } \\
\text { business/ } \\
\text { farming }\end{array}$ & & & & & & & & & \\
\hline $\begin{array}{l}\ldots \\
40\end{array}$ & $\begin{array}{l}\ldots \\
\text { Transportation } \\
\text { Cost }\end{array}$ & & & & & & & & & \\
\hline
\end{tabular}

Sumber: Analisis Penulis, 2017

Hasil isian kuesioner dipakai untuk menghitung (1) indeks Kapabilitas Masyarakat (Cci) yang merupakan indikator dari tingkat kesejahteraan dan (2) Indeks Daya Dukung Tempat terhadap kapabilitas (PCSi) yang akan dipakai untuk menilai kualitas tempat. $C$ Ci dihitung dengan rumus $=1 / 8 \mathrm{AF}^{2}$ dimana $\mathrm{A}$ adalah rerata skor persepsi terhadap ketersediaan/peningkatan seluruh aset dan $\mathrm{F}$ adalah rerata skor persepsi kemanfaatan seluruh aset. Pcsi dihitung dengan rumus yang sama, namun A dan $\mathrm{F}$ hanya ditentukan dari aset dalam kelopok PTA, SIA, dan EIA. Sedangkan nilai peran tempat sebagai multiplier atau deflator dapat dihitung menggunakan rumus Pcsi/ABS (Pcsi-Cci). Angkaangka yang mewakili $A$ dan $F$ diperoleh dari rerata jawaban responden terhadap pertanyaan terkait ketersediaan (A) dan fungsi aset (F). Hasil survei dianalisis dengan analisis korelasi dan analisis faktor.

Uji korelasi dilakukan untuk mengungkap keterkaitan aset tempat dan kapabilitas dengan ungkapan perasaan kebahagiaan. Sedangkan analisis faktor dilakukan untuk mengidentifikasi hubungan antar sejumlah variabel sehingga dapat dibentuk kumpulan variabel yang dalam penelitian ini disebut sebagai "aspek" yang diinterpretasikan sebagai faktor pembentuk tingkat kapabilitas. Tinggi rendahnya kontribusi faktor terhadap tingkat 
kapabilitas masyarakat ditunjukkan dengan nilai loading factor yang tertera dalam hasil output analisis SPSS.

Lokasi survei terbagi menjadi lima (5) klaster (lima desa/kelurahan dari 5 kecamatan) yang menggambarkan gradasi tingkat kekotaan di Kawasan Aglomerasi Perkotaan di DIY yaitu (1) Desa Caturtunggal, Kecamatan Depok, (2) Desa Purwomartani, Kecamatan Kalasan, (3) Desa Sidoagung, Kecamatan Godean, (4) Kelurahan Ngampilan, Kecamatan Ngampilan, dan (5) Desa Pendowoharjo, Kecamatan Sewon. Sebaran dari desa-desa sampel dan karakterina dapat dilihat pada gambar 2 dan tabel 2.

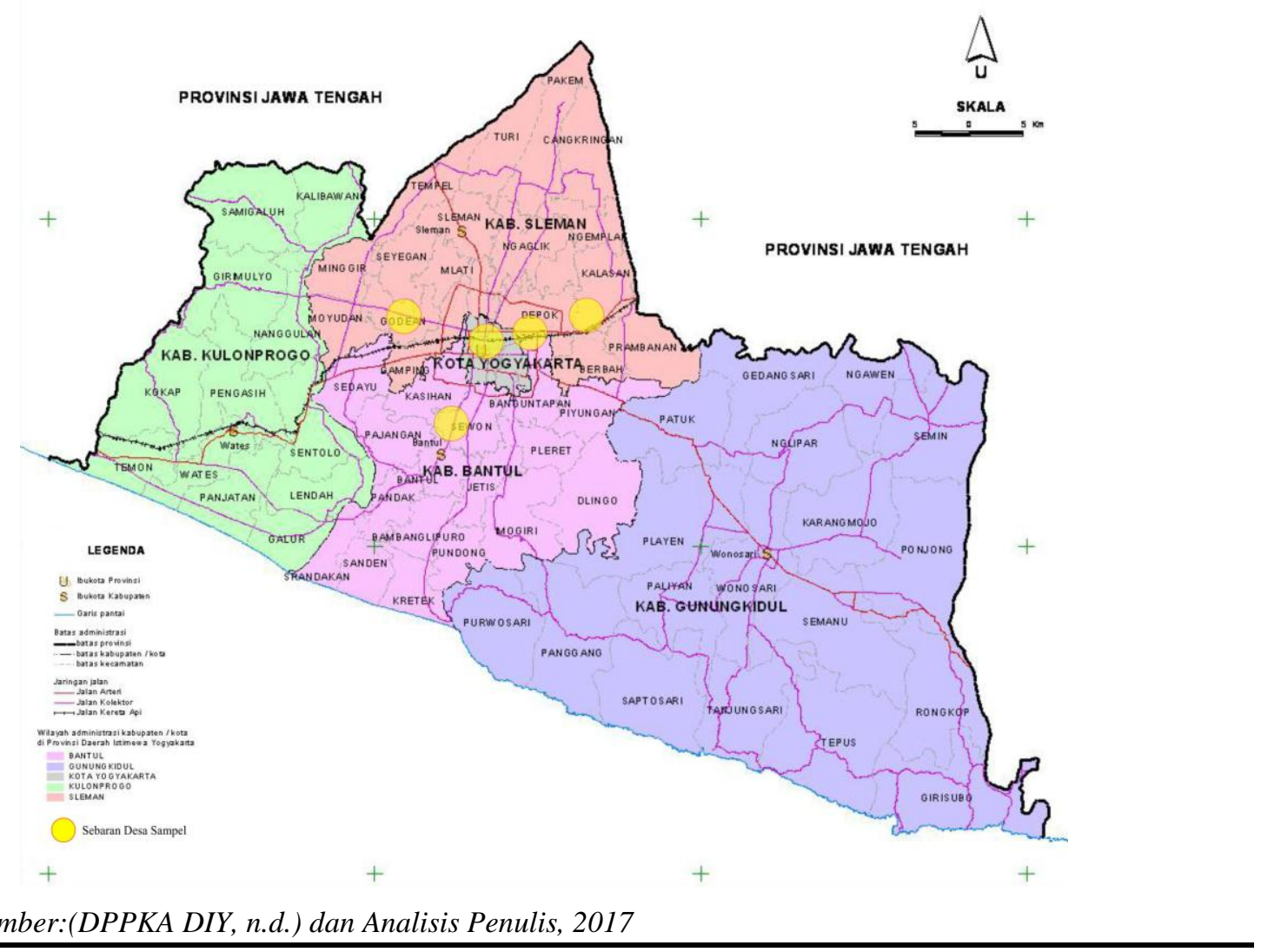

Gambar 2. Peta Sebaran Desa Sampel

Tabel 2. Tabel Profil/ Karakteristik Lokasi Penelitian

\begin{tabular}{|c|c|c|c|c|c|c|}
\hline No & Desa/Kec & Luas & Pdd & Karakter Lokasi & $\begin{array}{l}\% \text { lahan } \\
\text { terbangun }\end{array}$ & $\begin{array}{l}\text { Fasilitas Umum } \\
\text { dominan }\end{array}$ \\
\hline (1) & (2) & (3) & (4) & (5) & (6) & (7) \\
\hline 1 & $\begin{array}{l}\text { Caturtunggal/Depok } \\
\text { (menempel kota, } \\
\text { bagian dari yang } \\
\text { ditetapkan sebagai } \\
\text { kawasan aglomerasi } \\
\text { perkotaan } \\
\text { Yogyakarta) }\end{array}$ & $\begin{array}{l}1104 \\
\text { ha }\end{array}$ & 81.715 & $\begin{array}{l}\text { Hampir } 0.25 \% \text { dihuni oleh } \\
\text { mahasiswa. Banyak berdiri } \\
\text { bangunan yang berfungsi } \\
\text { sebagai kos-kos } \\
\text { an/penginapan dan fasilitas } \\
\text { perdagangan \& jasa. Memiliki } \\
\text { letak strategis yaitu } \\
\text { berdekatan dengan pusat } \\
\text { pendidikan }\end{array}$ & 902,92 ha & $\begin{array}{l}\text { Fasilitas } \\
\text { Perdagangan, } \\
\text { terutama } \\
\text { Restoran }\end{array}$ \\
\hline 2 & $\begin{array}{l}\text { Purwomartani/Kalas } \\
\text { an (tidak menempel, } \\
\text { tidak berkembnagan } \\
\text { karena perambatan) }\end{array}$ & $\begin{array}{l}1.205 \\
, 08 \\
\text { ha }\end{array}$ & 40.080 & $\begin{array}{l}\text { Merupakan kawasan } \\
\text { pedesaan semi perkotaan } \\
\text { yang masih memiliki area } \\
\text { persawahan. Seimbang antara } \\
\text { penduduk asli dan pendatang }\end{array}$ & 521,54 ha & $\begin{array}{l}\text { Fasilitas } \\
\text { Perdagangan, } \\
\text { terutama } \\
\text { Warung Kios }\end{array}$ \\
\hline
\end{tabular}




\begin{tabular}{|c|c|c|c|c|c|c|}
\hline No & Desa/Kec & Luas & Pdd & Karakter Lokasi & $\begin{array}{l}\text { \% lahan } \\
\text { terbangun }\end{array}$ & $\begin{array}{l}\text { Fasilitas Umum } \\
\text { dominan }\end{array}$ \\
\hline (1) & (2) & (3) & (4) & (5) & (6) & (7) \\
\hline 3 & $\begin{array}{l}\text { Sidoagung/Godean } \\
\text { (berkembangan } \\
\text { karena perambatan } \\
\text { urbanisasi) }\end{array}$ & $\begin{array}{l}332 \\
\text { ha }\end{array}$ & 9.034 & $\begin{array}{l}\text { Merupakan kawasan semi } \\
\text { perkotaan dengan pasar } \\
\text { sebagai pusat kegiatan. Masih } \\
\text { dominan penduduak asli }\end{array}$ & 99,2 ha & $\begin{array}{l}\text { Fasilitas } \\
\text { Perdagangan, } \\
\text { terutama Pasar } \\
\text { dan Toko }\end{array}$ \\
\hline 4 & $\begin{array}{l}\text { Ngampilan/Kota } \\
\text { Yogyakarta (pusat } \\
\text { kota, paling awal } \\
\text { mengalami } \\
\text { urbaniasasi) }\end{array}$ & 45 ha & 10.540 & $\begin{array}{l}\text { didominasi oleh zona } \\
\text { perdagangan dan jasa, juga } \\
\text { relatif dekat dengan kawasan } \\
\text { wisata di pusat kota dan pusat } \\
\text { oleh-oleh khas Jogja }\end{array}$ & 41,79 ha & $\begin{array}{l}\text { Fasilitas } \\
\text { Perdagangan, } \\
\text { terutama Kios }\end{array}$ \\
\hline 5 & $\begin{array}{l}\text { Pendowoharjo/Sewo } \\
\mathrm{n} \text { (berkembangan } \\
\text { karena perambatan } \\
\text { urbanisasi) }\end{array}$ & $\begin{array}{l}698 \\
\text { ha }\end{array}$ & 24.510 & $\begin{array}{l}\text { Merupakan kawasan semi } \\
\text { perkotaan yang mulai } \\
\text { berkembang permukiman- } \\
\text { permukiman baru }\end{array}$ & 388 ha & $\begin{array}{l}\text { Fasilitas } \\
\text { Perdagangan, } \\
\text { terutama } \\
\text { fasilitas Toko }\end{array}$ \\
\hline
\end{tabular}

Sumber: Analisis Penulis, 2017

\section{HASIL DAN PEMBAHASAN}

\section{Korelasi Antara Kualitas Tempat dengan Kebahagiaan}

Sebagaimana rekap pada tabel 3, hasil kuisioner dari 192 responden menunjukkan kondisi kapabilitas masyarakat pada lokasi penelitian cukup baik $(\mathrm{Ci}=0,401)$ Angka 1,37 sebagai indeks ketersediaan aset menunjukkan bahwa secara agregat kualitas aset meningkat menjadi lebih baik. Sedangkan angka indeks kemanfaatan aset 1,437 menunjukkan bahwa kondisi aset membantu kegiatan hidup (functioning) masyarakat dengan cukup baik. Baik aset yang melekat ppada priadi dan keluarga maupun pada tempat menduakung perkembangan hidup masyarakat. Sedanngkan evaluasi diri terhadap tingkat kebahagiaan terukur pada angka 0,76 dalam skala antara 0-1. Sebagai catatan, ternyata angka ini tidak jauh berbeda dari survei BPS pada tahun ini yang sebesar 7,2 pada skala 1-10 (BPS DIY, 2017). Hal terpenting pada analisis dari data keseluruhan responden adalah korelasi antara indikator-indikator kapabilitas dengan indikator tingkat kebahagiaan. Berikut adalah hasil analisis tersebut dengan menggunakan program SPSS.

Tabel 3. Hasil Korelasi

\begin{tabular}{lccl}
\hline & Nilai & $\begin{array}{c}\text { Korelasi } \\
\text { dgn H }\end{array}$ & Kategori \\
\hline \multicolumn{1}{c}{$(1)$} & $(2)$ & $(3)$ & (4) \\
\hline H (indeks kebahagiaan) & 7,644 & & \\
A (indeks peningkatan aset) & 1,377 & $.339 \star \star$ & cukup \\
F (indeks kemanfaatan aset) & 1,437 & $.194^{\star}$ & kurang \\
CI (indeks kapabilitas) & 0,401 & $.268^{\star \star}$ & cukup \\
Pcsi (indeks dukungan tempat thd kapabilitas dari SIA, EIA, TPA) & 0,369 & $.261^{\star \star}$ & cukup \\
& & & tidak \\
IIA (indeks kapabilitas dari kualitas manusia) & & 0,038 & berkorelasi \\
TIA (indeks kapabilitas dari harta benda) & & $.358^{\star \star}$ & cukup \\
Place's multiplier (koefisen tempat sbg pengganda kapabilitas) & 31,618 & $.279^{\star \star}$ & cukup \\
\hline
\end{tabular}

Sumber: Analisis Penulis, 2017

Korelasi tertinggi adalah antara indeks kebahagiaan dengan indeks peningkatan aset, sedangkan korelasi indeks dukungan tempat dengan kebagiaan ada pada urutan ke 5 . Namun dengan menggabungkan perhatian pada koefisien tempat sebagai pengganda, dapat diambil pemahaman bahwa peran tempat bagi kebahagiaan cukup berarti. Angka 
yang cukup besar di atas 1 ini menunjukkan bahwa tempat dapat mendukung masyarakat dalam mengembangkan asetnya.

\section{Pengelompokan Aspek Kualitas Tempat}

Analisis faktor dilakukan untuk mengidentifikasi faktor pengaruh kualitas. Sebelumnya telah dilakukan uji ketercukupan sampling dengan metode Kaiser Meyer Olkin/KMO yang menghasilkan angka 0,790 yang berarti data cukup dan layak (Widarjono, 2010). Sedangkan analisis Measure of Sampling Adequency/MSA menghasilkan nilai MSA $\geq 0,5$ pada 40 aset menunjukan data dapat dianalisis lebih lanjut (mengacu standar Hair, et.al (2010) dan Santosa (2002)). Principal Component Analysis (PCA) dengan kriteria bahwa faktor dengan nilai akar ciri $\geq 1$ dianggap signifikan (Hair, J.F. et al., 2010) menghasilkan 11 kelompok faktor sebagaimana dapat dilihat pada hasil tabel output gambar 3 berikut:

\begin{tabular}{|c|c|c|c|c|c|c|c|c|c|}
\hline \multicolumn{10}{|c|}{ Total Variance Explained } \\
\hline \multirow[b]{2}{*}{ Component } & \multicolumn{3}{|c|}{ Initial Eigenvalues } & \multicolumn{3}{|c|}{ Extraction Sums of Squared Loadings } & \multicolumn{3}{|c|}{ Rotation Sums of Squared Loadings } \\
\hline & Total & $\%$ of Variance & Cumulative $\%$ & Total & $\%$ of Variance & Cumulative \% & Total & $\%$ of Variance & Cumulative $\%$ \\
\hline 1 & 9.217 & 23.042 & 23.042 & 9.217 & 23.042 & 23.042 & 4.318 & 10.794 & 10.794 \\
\hline 2 & 3.732 & 9.330 & 32.372 & 3.732 & 9.330 & 32.372 & 3.587 & 8.967 & 19.761 \\
\hline 3 & 3.021 & 7.554 & 39.926 & 3.021 & 7.554 & 39.926 & 3.336 & 8.341 & 28.101 \\
\hline 4 & 2.391 & 5.976 & 45.902 & 2.391 & 5.976 & 45.902 & 3.204 & 8.011 & 36.112 \\
\hline 5 & 2.094 & 5.236 & 51.138 & 2.094 & 5.236 & 51.138 & 2.379 & 5.949 & 42.061 \\
\hline 6 & 2.022 & 5.056 & 56.194 & 2.022 & 5.056 & 56.194 & 2.357 & 5.892 & 47.953 \\
\hline 7 & 1.510 & 3.775 & 59.969 & 1.510 & 3.775 & 59.969 & 2.216 & 5.540 & 53.494 \\
\hline 8 & 1.326 & 3.314 & 63.283 & 1.326 & 3.314 & 63.283 & 2.135 & 5.337 & 58.831 \\
\hline 9 & 1.269 & 3.172 & 66.455 & 1.269 & 3.172 & 66.455 & 1.812 & 4.530 & 63.361 \\
\hline 10 & 1.110 & 2.776 & 69.230 & 21.110 & 2.776 & $3 \quad 69.230$ & 1.787 & 4.468 & 67.829 \\
\hline 11 & 1.044 & 2.610 & 71.841 & \begin{tabular}{l|l}
2 & 1.044 \\
\end{tabular} & 2.610 & \begin{tabular}{l|l}
71.841 \\
\end{tabular} & 1.605 & 4.011 & 71.841 \\
\hline 12 & .911 & 2.277 & 74.118 & & & & & & \\
\hline 13 & .799 & 1.998 & 76.116 & & & & & & \\
\hline 14 & .790 & 1.975 & 78.091 & & & & & & \\
\hline 15 & .710 & 1.775 & 79.866 & & & & & & \\
\hline 16 & .668 & 1.669 & 81.535 & & & & & & \\
\hline 17 & .611 & 1.528 & 83.063 & & & & & & \\
\hline 18 & .595 & 1.487 & 84.550 & & & & & & \\
\hline 19 & .555 & 1.387 & 85.937 & & & & & & \\
\hline 20 & .480 & 1.199 & 87.137 & & & & & & \\
\hline
\end{tabular}

Sumber: Analisis Penulis, 2017

\section{Gambar 3. Faktor yang Terbentuk (Aspek)}

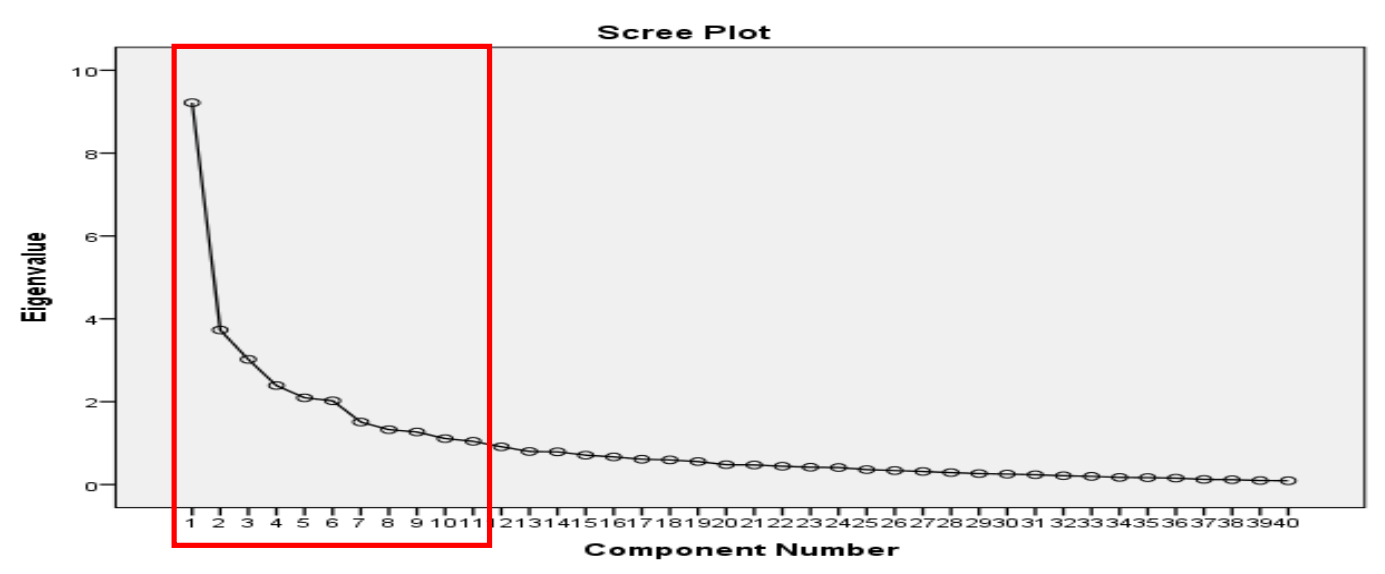

Sumber: Analisis Penulis, 2017 
Ke-11 aspek yang terbentuk memiliki nilai presentase kumulatif keragaman $\leq 95 \%$ menunjukkan keterpenuhan kriteria untuk menjadi faktor determinan. Sedangkan kriteria scree test dilakukan dengan membuat plot antara jumlah faktor determinan yang terbentuk (sumbu horizontal) dengan akar ciri (sumbu vertikal). Kurva yang terbentuk semakin melandai dimulai dari titik pada faktor determinan ke 11. Ke-11 faktor pada grafik yang belum melandai adalah yang memenuhi kriteria sebagai faktor.

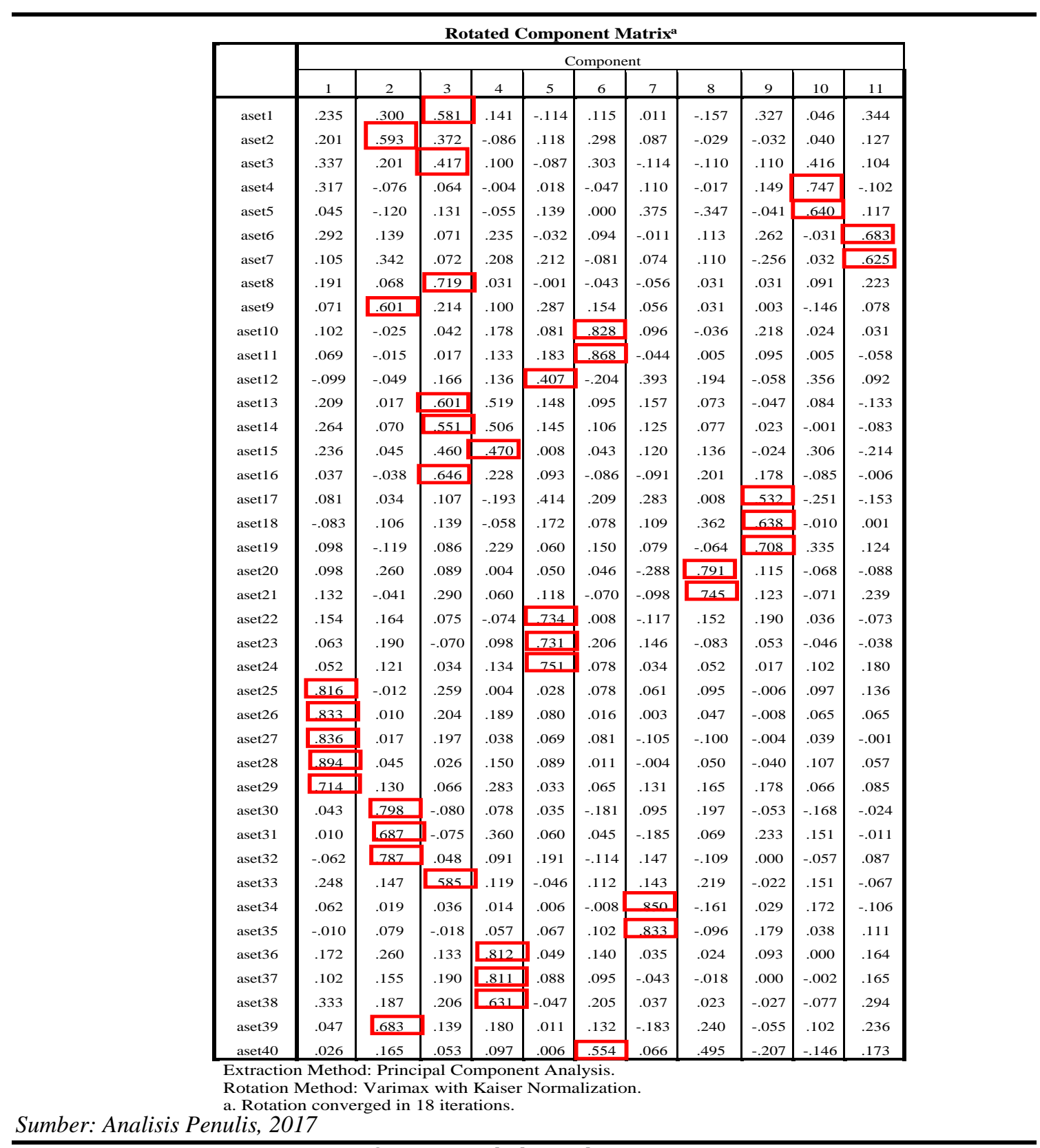

Gambar 5. Nilai Loading Factor

Tahap selanjutnya adalah menentukan estimasi nilai loading untuk menetapkan variabel penyusun faktor determinan mengunakan rotasi orthogonal yaitu varimax. Berdasar (Hair, J. F, 1998; Johnson, Richard A. \& Wichern, Dean W, 2013; Rummel, R. J., 1970) merotasi matriks loading factor menyebabkan setiap peubah asal mempunyai korelasi yang tinggi terhadap faktor tertentu saja, sedangkan faktor lain mempunyai 
korelasi relatif sehingga setiap faktor akan lebih mudah diinterpretasikan. Hasil analisis tahap ini menghasilkan nilai loading factor yang telah terotasi (Gambar 5). Nilai loading factor yang paling tinggi pada tiap aset menunjukkan klasifikasi aset tersebut. Masingmasing kelompok faktor diberi nama yang disesuaikan dengan aset-aset pembentuknya sebagaiana dapat dilihat pada tabel berikut:

Tabel 4. Pengelompokan Faktor determinan berpengaruh terhadap Kualitas Hidup

\begin{tabular}{|c|c|c|c|c|}
\hline \multicolumn{3}{|c|}{$\begin{array}{c}\text { Kelompok } \\
\text { Faktor/Aspek }\end{array}$} & Komponen Aset Terkait & $\begin{array}{l}\text { Loading } \\
\text { Factor }\end{array}$ \\
\hline \multicolumn{2}{|r|}{ (1) } & & (2) & (3) \\
\hline \multirow[t]{5}{*}{1.} & \multirow{5}{*}{$\begin{array}{l}\text { Dukungan tempat } \\
\text { bagi Interaksi } \\
\text { sosial }\end{array}$} & 28. & Ada tidaknya solidaritas (Community Solidarity) & 0.894 \\
\hline & & 27. & $\begin{array}{l}\text { Ada tidaknyaGotong royong/kerja } \\
\text { samasosial/budaya/ekonomi (Community Cooperation) }\end{array}$ & 0.836 \\
\hline & & 26. & $\begin{array}{l}\text { Ada tidaknyatingkat kepercayaan antar anggota } \\
\text { masyarakat termasuk saling menjaga, tdk saling curang } \\
\text { dan menjahati (Social Trust) }\end{array}$ & 0.833 \\
\hline & & 25. & $\begin{array}{l}\text { Ada tidaknyakekerabatan/organisasi kegiatan } \\
\text { sosial/budaya (Comunity Memberships/Kindships) }\end{array}$ & 0.816 \\
\hline & & 29. & $\begin{array}{l}\text { Ada tidaknya forum - forum musyawarah (Availability of } \\
\text { Comunity Forum) kesempatan menyalurkan aspirasi/turut } \\
\text { serta dalam kegiatan pembangunan (Opportunity to } \\
\text { Aspirate in Public Decision) }\end{array}$ & 0.714 \\
\hline \multirow[t]{6}{*}{2.} & \multirow{6}{*}{$\begin{array}{l}\text { Dukungan tempat } \\
\text { bagi pendapatan } \\
\text { keluarga }\end{array}$} & 30. & $\begin{array}{l}\text { Kemudahan mendapatkan kredit/pinjaman bank dll } \\
\text { (Access to Credits) }\end{array}$ & 0.798 \\
\hline & & 32. & $\begin{array}{l}\text { Tingkat kesempatan untuk memulai/menjalankan } \\
\text { usaha/bisnis (Opportunity to Set Up Business) }\end{array}$ & 0.787 \\
\hline & & 31. & Kemudahan mendapatkan pekerjaan (Access to Jobs) & 0.687 \\
\hline & & 39. & $\begin{array}{l}\text { Kemampuan membeli/mendapatkan/sewa rumah Access } \\
\text { to Housing) }\end{array}$ & 0.683 \\
\hline & & 9. & $\begin{array}{l}\text { Ketersedian ruang/lahan kota untuk mendukung peluang } \\
\text { produktivitas usaha (space productivity-support) }\end{array}$ & 0.601 \\
\hline & & 2. & $\begin{array}{l}\text { Ada tidaknyaRuang/Tanah utk berusaha/bisnis/bertani } \\
\text { (space/land to generate income) }\end{array}$ & 0.593 \\
\hline \multirow[t]{7}{*}{3.} & \multirow{7}{*}{$\begin{array}{l}\text { Dukungan tempat } \\
\text { bagi pemenuhan } \\
\text { Kebutuhan dasar } \\
\text { bermukim }\end{array}$} & 8. & $\begin{array}{l}\text { Tingkat kualitas lingkungan (kebersihan, air, udara, tanah } \\
\text { dll) (Quality of local environment, related to air, water, soil, } \\
\text { built env., public space, landscape) }\end{array}$ & 0.719 \\
\hline & & 16. & $\begin{array}{l}\text { Ketersediaan Sarana Pemenuhan Air Bersih (Availability of } \\
\text { Water Supply) }\end{array}$ & 0.646 \\
\hline & & 13. & $\begin{array}{l}\text { Ketersediaan fasilitas Pendidikan (Availability of Education } \\
\text { facilities) }\end{array}$ & 0.601 \\
\hline & & 33. & $\begin{array}{l}\text { Kemudahan mendapatkan barang konsumsi sehari-hari } \\
\text { (Access to Daily necessities/material Consumption) }\end{array}$ & 0.585 \\
\hline & & 1. & $\begin{array}{l}\text { Ada tidaknyaRuang/Tanah utk bertempat tinggal } \\
\text { (space/land to stay) }\end{array}$ & 0.581 \\
\hline & & 14. & $\begin{array}{l}\text { Ketersediaan fasilitas Pelayanan Kesehatan (Availability of } \\
\text { Health facilities) }\end{array}$ & 0.551 \\
\hline & & 15. & Ketersediaan Pasar (Availability of Market facilities) & 0.47 \\
\hline \multirow[t]{5}{*}{4.} & \multirow{5}{*}{$\begin{array}{l}\text { Investasi Kualitas } \\
\text { Sumber daya } \\
\text { manusia }\end{array}$} & 36. & Tingkat Biaya Pemeliharaan Kesehatan (Health Cost) & 0.812 \\
\hline & & 37. & $\begin{array}{l}\text { Ada tidaknya Akses pada Asuransi Kesehatan (Acces to } \\
\text { Health Insurance) }\end{array}$ & 0.811 \\
\hline & & 38. & $\begin{array}{l}\text { Tingkat Biaya pendidikan Anak (Eduation Cost for } \\
\text { Children) }\end{array}$ & 0.631 \\
\hline & & 24. & $\begin{array}{l}\text { Ada tidaknya daya juang/ketangguhan diri/keluarga untuk } \\
\text { maju (Strugling Spirit/Survival Power) }\end{array}$ & 0.751 \\
\hline & & 22. & $\begin{array}{l}\text { Ada tidaknya kemampuan berkomunikasi dengan } \\
\text { masyarakat, relasi bisnis. Orang asing (Communication } \\
\text { Skill) }\end{array}$ & 0.734 \\
\hline
\end{tabular}




\begin{tabular}{|c|c|c|c|c|}
\hline \multicolumn{3}{|c|}{$\begin{array}{c}\text { Kelompok } \\
\text { Faktor/Aspek }\end{array}$} & Komponen Aset Terkait & $\begin{array}{l}\text { Loading } \\
\text { Factor }\end{array}$ \\
\hline \multirow{2}{*}{\multicolumn{2}{|c|}{ (1) }} & & (2) & (3) \\
\hline & & 23. & $\begin{array}{l}\text { Ada tidaknya kreativitas dan daya inovasi diri/keluarga } \\
\text { mencipta produk barang/jasa (Creativity and Innovation) }\end{array}$ & 0.731 \\
\hline 5. & $\begin{array}{l}\text { Dukungan } \\
\text { Tempat bagi } \\
\text { Keselamatan diri }\end{array}$ & 12. & $\begin{array}{l}\text { Ada tidaknya keamanan dari bencana (alam, kebakaran, } \\
\text { banjir dll) (Freedom from disaster/availability of disaster } \\
\text { mitigation) }\end{array}$ & 0.407 \\
\hline \multirow[t]{3}{*}{6.} & $\begin{array}{l}\text { Dukungan } \\
\text { Tempat bagi } \\
\text { Kebutuhan }\end{array}$ & 11. & $\begin{array}{l}\text { Tingkat kualitas sarana prasarana transportasi publik } \\
\text { (keamanan/kenyamanan/kelancaran) (Quality of Public } \\
\text { Transportation) }\end{array}$ & 0.868 \\
\hline & mobilitas & 10. & $\begin{array}{l}\text { Ketersediaan Infrastruktur Transportasi Publik (Availability } \\
\text { of Public Transport Infrastructure) }\end{array}$ & 0.828 \\
\hline & & 40. & $\begin{array}{l}\text { Tingkat biaya transportasi yang harus dikeluarkan } \\
\text { (Transportation Cost) }\end{array}$ & 0.554 \\
\hline \multirow[t]{2}{*}{7.} & $\begin{array}{l}\text { Dukungan tempat } \\
\text { bagi kebutuhan }\end{array}$ & 34. & $\begin{array}{l}\text { Kemudahan mendapatkan bahan baku produksi (Access to } \\
\text { Production Inputs) }\end{array}$ & 0.85 \\
\hline & jejaring bisnis & 35. & $\begin{array}{l}\text { Kemudahan memasarkan hasil-hasil produksi bagi para } \\
\text { pelaku usaha (Oportunity to Products Marketing) }\end{array}$ & 0.833 \\
\hline \multirow[t]{3}{*}{8.} & Keterpenuhan & 20. & Tingkat pendidikan diri/keluarga (Education Level) & 0.791 \\
\hline & $\begin{array}{l}\text { Investasi } \\
\text { peningkatan }\end{array}$ & 21. & Tingkat kualitas kesehatan diri/keluarga (Health quality) & 0.745 \\
\hline & $\begin{array}{l}\text { peningkatan } \\
\text { kualitas SDM }\end{array}$ & 19. & $\begin{array}{l}\text { Ketersediaan jaringan internet untuk umum (Internet } \\
\text { Access/network) }\end{array}$ & 0.708 \\
\hline & Dukungan tempat & 18. & Ketersediaan perpustakaan umum (Library) & 0.638 \\
\hline & $\begin{array}{l}\text { bagi pemenuhan } \\
\text { kebutuhan } \\
\text { informasi }\end{array}$ & 17. & $\begin{array}{l}\text { Ketersediaan fasilitas rekreasi (Availability of Recreational } \\
\text { facilities, such as public space, art perfomace facilities, or } \\
\text { Movie) }\end{array}$ & 0.532 \\
\hline & & 4. & $\begin{array}{l}\text { Kepemilikan alat komunikasi (telepon, } \mathrm{Hp} \text { ) (communication } \\
\text { tools such mobile phone) }\end{array}$ & 0.747 \\
\hline & $\begin{array}{l}\text { Kepemilikan alat } \\
\text { komunikasi }\end{array}$ & 5. & $\begin{array}{l}\text { Kepemilikan alat akses informasi Koran, Majalah, Radio, } \\
\text { TV, Internet }\end{array}$ & 0.64 \\
\hline & & 6. & $\begin{array}{l}\text { Tingkat Pendapatan/pemenuhan kebutuhan sehari-hari } \\
\text { (income/material for daily necessities) }\end{array}$ & 0.683 \\
\hline & $\begin{array}{l}\text { Kekayaan } \\
\text { keluarga }\end{array}$ & 7. & Ada tidaknyaTabungan (household saving) & 0.625 \\
\hline
\end{tabular}

Dari 11 kelompok faktor derterminan, dikenali tujuh (7) yang merupakan aspek dukungan tempat (yang berwarna abu-abu). Pembentuk faktor ini adalah atribut fisik tempat terutama berupa hadirnya sarana-prasarana.

\section{Elemen Fisik Tempat pembentuk Faktor Determinan Pendukung Kualitas Hidup Masyarakat}

Selain mengidentifikasi faktor determinan kualitas tempat melalui analisis kuantitatif, dilakukanlah eksplorasi terhadap elemen kualitas tempat dengan menggunakan teknik survei dengan pertanyaan terbuka untuk menggali hal-hal yang membuat responden nyaman berkegiatan dan suka dengan suasana di lingkungan tempat tinggal mereka. Pertanyaan digunakan untuk mengungkap komponen struktur ruang yang terbentuk oleh pola sebaran pusat-pusat/agregasi fasilitas layanan dalam sistem permukiman, serta untuk mengungkap bentukan fisik 2 maupun 3 dimensi dari lingkungan. Ragam dan frekuensi jawaban responden terhadap pertanyaan kedua tergambarkan pada gambar 6 .

Sebagaimana terhadap kusioner tertutup, terhadap jawaban-jawaban dari pertanyaan terbuka juga dilakukan analisis loading factor yang hasilnya menunjukkan ranking kontribusi fasilitas dan jaringan terhadap pemenuhan kebutuhan dasar bermukim sebagaimana pada tabel 5 dan table 6 . Elemen "ketersediaan fasilitas pelayanan kesehatan" 
memiliki nilai tertinggi sedangkan jika dilihat dari prasarana yang berbentuk jaringan utilitas, nilai tertingginya adalah elemen " jaringan layanan listrik".

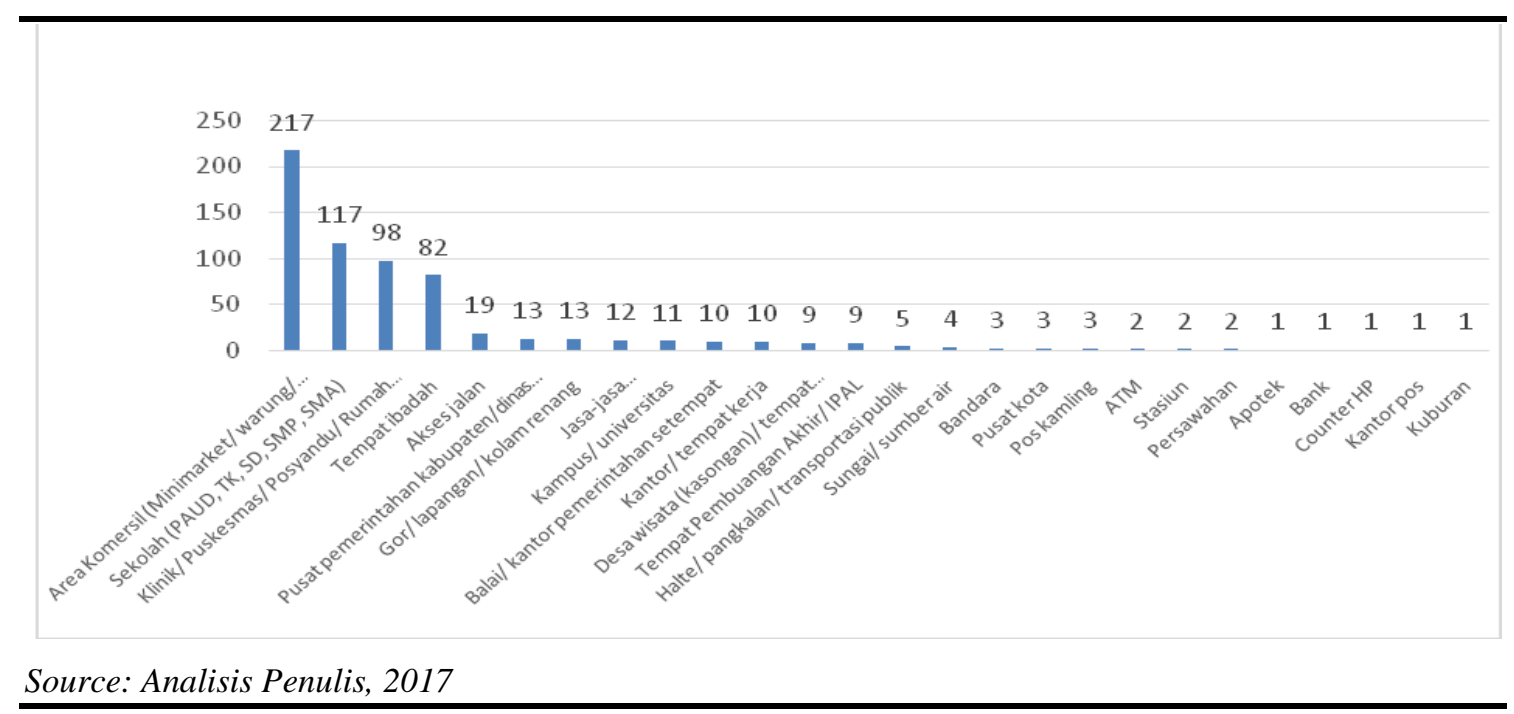

Gambar 6. Frekuensi Jawaban Responden mengenai Ketersediaan Fasilitas

Tabel 5. Elemen Fasilitas Penting Pembentuk Dukungan Tempat Bagi Kebutuhan Dasar Bermukim Communalities

\begin{tabular}{|c|c|c|}
\hline & Initial & Extraction \\
\hline Kedekatan dengan sekolah & 1.000 & 0.602 \\
\hline Kedekatan dengan Area Komersial & 1.000 & 0.496 \\
\hline Kedekatan dengan tempat ibadah & 1.000 & 0.526 \\
\hline Ketersediaan fasilitas pelayanan kesehatan & 1.000 & 0.604 \\
\hline Akses jalan & 1.000 & 0.431 \\
\hline
\end{tabular}

Sumber: Analisis Penulis, 2017

Tabel 6. Elemen Jaringan Penting Pembentuk Dukungan Tempat Bagi Kebutuhan Dasar Bermukim Communalities

\begin{tabular}{|lcc|}
\hline \multicolumn{1}{|c}{} & Initial & Extraction \\
\hline Layanan Listrik & 1.000 & 0.698 \\
\hline Layanan Air Bersih & 1.000 & 0.677 \\
Layanan Transportasi Publik & 1.000 & 0.145 \\
\hline
\end{tabular}

Extraction Method: Principal Component Analysis.

Sumber: Analisis Penulis, 2017

Tabel 7 Elemen sosial penting pembentuk dukungan tempat bagi kebutuhan interaksi sosial Communalities

\begin{tabular}{lcc}
\hline & Initial & Extraction \\
\hline Kekerabatan/organisasi kegiatan sosial/budaya & 1.000 & 0.732 \\
Tingkat kepercayaan antar anggota masyarakat termasuk saling & 1.000 & 0.806 \\
menjaga, tidak saling curang dan menjahati & & 0.736 \\
Gotong royong/kerjasama sosial/budaya/ekonomi & 1.000 & 0.822 \\
\hline Solidaritas & 1.000 & 0.621 \\
\hline Keberadaan forum - forum musyawarah & 1.000 & \\
\hline
\end{tabular}

Extraction Method: Principal Component Analysis.

Sumber: Analisis Penulis, 2017 
Tabel 7 menunjukkan bahwa aset "Solidaritas" adalah yang tertinggi yaitu 0.822 yang disusul dengan tingkat kepercayaan antar anggota masyarakat pemukim. Yang menarik dari ekplorasi lebih lanjut adalah bahwa aset-aset sosial intangible yang menghasilkan kenyamanan interaksi sosial dipengaruhi oleh kualitas ruang publik. Elemen fisik lingkungan yang dirasa menjadi elemen yang secara signifikan mendukung interaksi sosial terlihat pada tabel 8.

Tabel 8. Elemen tata bangunan dan lingkungan penting pembentuk dukungan tempat bagi kebutuhan dasar bermukim

Communalities

\begin{tabular}{lcc}
\hline & & \\
\hline Kenyamanan ruang publik karena Kerindangan & Initial & Extraction \\
Kenyamanan ruang publik karena Kepadatan bangunan & 1.000 & 0.732 \\
Kenyamanan ruang jalan & 1.000 & 0.806 \\
\hline Kenyamanan ruang publik karena sirkulasi udaranya & 1.000 & 0.736 \\
\hline Kenyamanan ruang publik karena karena tata kelola air hujan & 1.000 & 0.822 \\
\hline
\end{tabular}

Kenyamanan ruang publik karena sirkulasi cahaya

Extraction Method: Principal Component Analysis.

Sumber: Analisis Penulis, 2017

Hasil analisis faktor terhadap elemen-elemen yang disebut responden sebagaimana tertuang pada tabel 8 merepresentasikan pentingnya kualitas tata bangunan dan lingkungan bagi terbentuknya kohesivitas sosial. Bentukan fisik yang menentukan iklim mikro, seperti sirkulasi udara dan cahaya yang ditentukan oleh kerindangan dan tata penetrasi sinar matahari di ruang publik dianggap sangat signifikan memfasiitasi terjadinya interaksi sosial.

\section{Pengaruh Tingkat kekotaan bagi Kualitas Hidup (Kapabilitas dan Kebahagiaan)}

Penelaitian ini menemukan konsistensi ranking antara Indeks Kebahagiaan $(\mathrm{H})$ dengan Indeks Kapabilitas (CI), Indeks Dukungan Tempat bagi Kapabilitas (Pcsi), serta Koefisien Tempat sebagai pengganda/deflator yang selaras dengan derajat kekotan dai lokasi sebagaimana pada tabel 9 .

Tabel 9. Hasil Penilaian Kuesioner Per Desa Sampel

\begin{tabular}{|c|c|c|c|c|c|c|c|c|c|}
\hline Place & $\begin{array}{c}\text { Res- } \\
\text { pondents }\end{array}$ & $\begin{array}{c}\text { Assets } \\
\text { Availability } \\
\text { Index (A) }\end{array}$ & $\begin{array}{l}\text { Assets } \\
\text { Benefits } \\
\text { Index } \\
\text { (F) }\end{array}$ & $\begin{array}{l}\text { Capability } \\
\text { Index (Ci) }\end{array}$ & $\begin{array}{c}\text { Place } \\
\text { Assets } \\
\text { Availability } \\
\text { Index (A of } \\
\text { PTA, SIA, } \\
\text { EIA) }\end{array}$ & $\begin{array}{c}\text { Place } \\
\text { Assets } \\
\text { Benefits } \\
\text { Index } \\
\text { (F of } \\
\text { PTA, } \\
\text { SIA, } \\
\text { EIA) }\end{array}$ & $\begin{array}{c}\text { Place } \\
\text { Capability } \\
\text { Supporting } \\
\text { Index } \\
\text { (Pcsi) }\end{array}$ & $\begin{array}{c}\text { Place } \\
\text { Co- } \\
\text { eficient }\end{array}$ & $\begin{array}{l}\text { Happines } \\
\text { Index } \\
\text { (H) }\end{array}$ \\
\hline (1) & (2) & (3) & (4) & (5) & (6) & (7) & (8) & (9) & (10) \\
\hline Catur Tunggal & 45 & 1,507 & 1,411 & 0,451 & 1,42 & 1,368 & 0,414 & 11,189 & 7,717 \\
\hline Purwomartani & 41 & 1,634 & 1,498 & 0,468 & 1,57 & 1,499 & 0,452 & 28,250 & 8,415 \\
\hline Sidoagung & 35 & 1,316 & 1,398 & 0,385 & 1,22 & 1,358 & 0,348 & 9,405 & 7,371 \\
\hline Pendowoharjo & 35 & 1,059 & 1,321 & 0,271 & 0,95 & 1,299 & 0,243 & 8,679 & 7,114 \\
\hline Ngampilan & 36 & 1,371 & 1,554 & 0,43 & 1,34 & 1,496 & 0,389 & 9,488 & 7,600 \\
\hline Total & 192 & & & & & & & & \\
\hline \multicolumn{10}{|l|}{ Responden } \\
\hline Averag & & 1,377 & 1,436 & 0,401 & 1,299 & 1,404 & 0,369 & 13,402 & 7,643 \\
\hline
\end{tabular}

Sumber: Analisis Penulis, 2017 
Analisis menunjukkan bahwa tingkat dukungan tempat terhadap kebahagiaan dan kapabilitas berkorelasi dengan banyaknya elemen yang dinilai kurang dari 1 yang mengindikasikan bahwa aset dianggap tidak berubah atau bahkan memburuk sebagaimana terlihat pada tabel 10 .

Tabel 10. Aset Dinilai Kurang pada Tiap Desa Sampel

\begin{tabular}{|c|c|c|c|c|c|c|}
\hline No & Komponen/Asset & $\begin{array}{c}\text { (1) } \\
\text { Catur } \\
\text { Tunggal } \\
\text { Depok } \\
\text { Perkotaan }\end{array}$ & $\begin{array}{c}\text { (2) } \\
\text { Purwomartani } \\
\text { Kalasan } \\
\text { Pedesaan } \\
\text { bertransformasi }\end{array}$ & $\begin{array}{c}\text { (3) } \\
\text { Sidoagun } \\
\text { g } \\
\text { Godean } \\
\text { Pedesaan }\end{array}$ & $\begin{array}{c}(4) \\
\text { Pendowoharjo } \\
\text { Sewon } \\
\text { Pedesaan } \\
\text { bertransformasi }\end{array}$ & $\begin{array}{l}(5) \\
\text { Ngampilan } \\
\text { Ngampilan } \\
\text { Tengah } \\
\text { Kota } \\
\text { (Lama) }\end{array}$ \\
\hline (1) & (2) & (3) & (4) & (5) & (6) & (7) \\
\hline 1. & $\begin{array}{l}\text { Kepemilikan ruang/tanah } \\
\text { untuk bertempat tinggal } \\
\text { (space/land to stay) }\end{array}$ & & & & & \\
\hline 2. & $\begin{array}{l}\text { Kepemilikan ruang/tanah } \\
\text { untuk berusaha/bisnis/bertani } \\
\text { (space/land to generate } \\
\text { income) }\end{array}$ & & & & & \\
\hline 3. & $\begin{array}{l}\text { Kepemilikan alat transportasi } \\
\text { (sepeda, motor, mobil, dll) } \\
\text { (Transportation tools such as } \\
\text { bicycle, motorcycle, car, etc) }\end{array}$ & & & & & \\
\hline 4. & $\begin{array}{l}\text { Kepemilikan alat komunikasi } \\
\text { (telepon, HP) (Communication } \\
\text { tools such as mobile phone, } \\
\text { landline) }\end{array}$ & & & & & \\
\hline 5. & $\begin{array}{l}\text { Kepemilikan alat akses } \\
\text { informasi (Koran, Majalah, } \\
\text { Radio, TV, Internet) }\end{array}$ & & & & & \\
\hline 6. & $\begin{array}{l}\text { Pendapatan/pemenuhan } \\
\text { kebutuhan sehari - hari } \\
\text { (income/material for daily } \\
\text { neccesities) }\end{array}$ & & & & & \\
\hline 7. & Tabungan (Household saving) & & & & & \\
\hline 8. & $\begin{array}{l}\text { Kualitas lingkungan } \\
\text { (kebersihan, air, udara, tanah, } \\
\text { dll) (Quality of local } \\
\text { environment, related to air, } \\
\text { water, soil, built environment, } \\
\text { public) }\end{array}$ & & & & & \\
\hline 9. & $\begin{array}{l}\text { Ketersediaan ruang/lahan kota } \\
\text { untuk mendukung peluang } \\
\text { produktivitas usaha (Space for } \\
\text { productivity support) }\end{array}$ & & & & & \\
\hline 10. & $\begin{array}{l}\text { Ketersediaan infrastruktur } \\
\text { transportasi publik (Availability } \\
\text { of Public Transport } \\
\text { Infrastructure) }\end{array}$ & & & & & \\
\hline 11. & $\begin{array}{l}\text { Kualitas sarana prasarana } \\
\text { transportasi publik } \\
\text { (keamanan/kenyamanan/kelan } \\
\text { caran) (Quality of Public } \\
\text { Transportation Supporting } \\
\text { Infrastructure }\end{array}$ & & & & & \\
\hline 12. & $\begin{array}{l}\text { Keamanan dan bencana (alam, } \\
\text { kebakaran, banjir, suicide, dll) } \\
\text { (Freedom from } \\
\text { disaster/availability of disaster }\end{array}$ & & & & & \\
\hline
\end{tabular}




\begin{tabular}{|c|c|c|c|c|c|c|}
\hline No & Komponen/Asset & $\begin{array}{c}\text { (1) } \\
\text { Catur } \\
\text { Tunggal } \\
\text { Depok } \\
\text { Perkotaan }\end{array}$ & $\begin{array}{c}\text { (2) } \\
\text { Purwomartani } \\
\text { Kalasan } \\
\text { Pedesaan } \\
\text { bertransformasi }\end{array}$ & $\begin{array}{c}(3) \\
\text { Sidoagun } \\
\mathrm{g} \\
\text { Godean } \\
\text { Pedesaan }\end{array}$ & $\begin{array}{c}\text { (4) } \\
\text { Pendowoharjo } \\
\text { Sewon } \\
\text { Pedesaan } \\
\text { bertransformasi }\end{array}$ & $\begin{array}{c}\text { (5) } \\
\text { Ngampilan } \\
\text { Ngampilan } \\
\text { Tengah } \\
\text { Kota } \\
\text { (Lama) } \\
\end{array}$ \\
\hline (1) & (2) & (3) & (4) & (5) & (6) & (7) \\
\hline & mitigation) & & & & & \\
\hline 13. & $\begin{array}{l}\text { Ketersediaan fasilitas } \\
\text { pendidikan (Availability of } \\
\text { Education Facilities) }\end{array}$ & & & & & \\
\hline 14. & $\begin{array}{l}\text { Ketersediaan fasilitas } \\
\text { pelayanan kesehatan } \\
\text { (Availability of Health } \\
\text { Facilities) }\end{array}$ & & & & & \\
\hline 15. & $\begin{array}{l}\text { Ketersediaan Pasar (Availability } \\
\text { of Market Facilities) }\end{array}$ & & & & & \\
\hline 16. & $\begin{array}{l}\text { Ketersediaan sarana } \\
\text { pemenuhan air bersih } \\
\text { (Availabilty of Water Supply) }\end{array}$ & & & & & \\
\hline 17. & $\begin{array}{l}\text { Ketersediaan fasilitas rekreasi } \\
\text { (Availability of recreational } \\
\text { facilities such as public space, } \\
\text { art performance facilities, or } \\
\text { movie/theathre }\end{array}$ & & & & & \\
\hline 18. & $\begin{array}{l}\text { Ketersediaan perpustakaan } \\
\text { umum (Library) }\end{array}$ & & & & & \\
\hline 19. & $\begin{array}{l}\text { Ketersediaan jaringan internet } \\
\text { untuk umum (Internal } \\
\text { access/network) }\end{array}$ & & & & & \\
\hline 20. & $\begin{array}{l}\text { Tingkat pendidikan } \\
\text { diri/keluarga (Education level) }\end{array}$ & & & & & \\
\hline 21. & $\begin{array}{l}\text { Kualitas kesehatan } \\
\text { diri/keluarga (Health Quality) }\end{array}$ & & & & & \\
\hline 22. & $\begin{array}{l}\text { Kemampuan berkomunikasi } \\
\text { dengan masyarakat, relasi } \\
\text { bisnis, orang asing } \\
\text { (Communication Skill) }\end{array}$ & & & & & \\
\hline 23. & $\begin{array}{l}\text { Kreativitas dan daya inovasi } \\
\text { diri/keluarga mencipta produk } \\
\text { barang/jasa (Creativity and } \\
\text { Innovation) }\end{array}$ & & & & & \\
\hline 24. & $\begin{array}{l}\text { Daya juang/ketangguhan } \\
\text { diri/keluarga untuk maju } \\
\text { (Strugling Spirit/survival } \\
\text { power) }\end{array}$ & & & & & \\
\hline 25. & $\begin{array}{l}\text { Kekerabatan/organisasi } \\
\text { kegiatan sosial/budaya } \\
\text { (Community } \\
\text { Membership/Kinships) }\end{array}$ & & & & & \\
\hline 26. & $\begin{array}{l}\text { Tingkat kepercayaan antar } \\
\text { anggota masyarakat termasuk } \\
\text { saling menjaga, tidak saling } \\
\text { curang dan menjahati (Social } \\
\text { Trust) }\end{array}$ & & & & & \\
\hline 27. & $\begin{array}{l}\text { Gotong royong/kerja sama } \\
\text { sosial/budaya/ekonomi } \\
\text { (Community Cooperation) }\end{array}$ & & & & & \\
\hline 28. & $\begin{array}{l}\text { Solidaritas (Community } \\
\text { solidarity) }\end{array}$ & & & & & \\
\hline 29. & Keberadaan forum - forum & & & & & \\
\hline
\end{tabular}




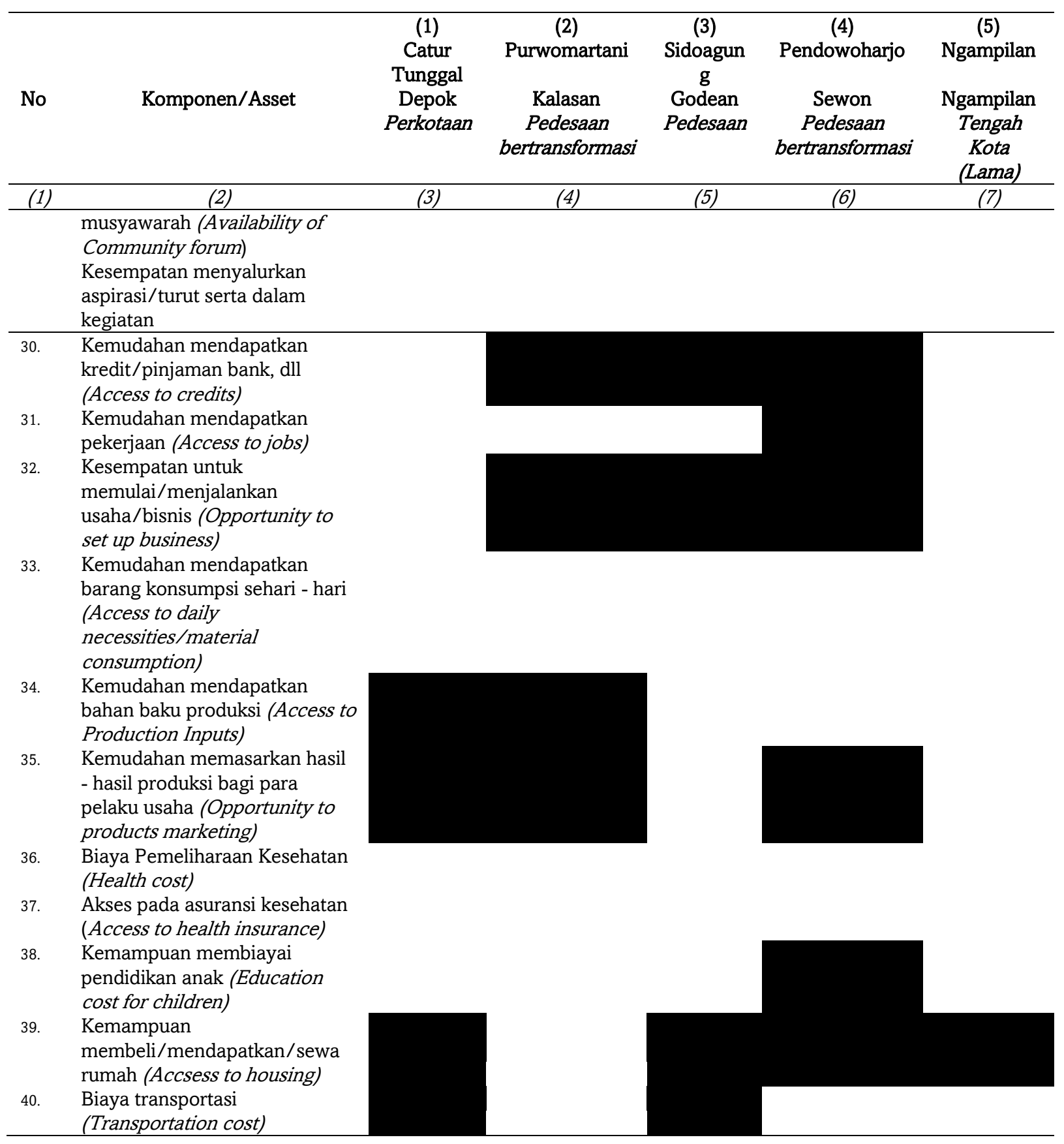

Sumber: Analisis Penulis, 2017

Dari keseluruhan desa sampel, aset-asetnterkaiat tempat berupa infrastruktur transportasi, ruang terbuka publik, dan perumahan secara umum dirasa kurang. Selain infrastrutur fisik, aset tempat yang dirasa kurang adalah kelompok aset institusi ekonomi (EIA). EIA memengaruhi kapabilitas masyarakat untuk mengembangkan usaha atau kemampuan finansial (affordabilitas) untuk memenuhi seperti perumahan, pendidikan anak, kesehatan, dan mobilitas. Sedangkan aset tempat berupa institusi sosial (SIA), seperti solidaritas, rasa saling percaya, kekerabatan, dan rasa gotong royong telah dievalusi sebagai cukup baik oleh hampir semua responden di seluruh desa sampel. Pencermatan terhadap data menunjukkan adanya relasi antara tahapan dan karakter urbanisasi dengan indeks kapabilitas dan kebahagiaan. Observasi per desa yang telah dilakukan memberikan indikasi bahwa kombinasi kekotaan dengan kelengkapan fasilitas dukungan yang tinggi 
terhadap pemenuhan kebutuhan dasar serta karakter kepadatan, tata bangunan dan lingkungan yang membentuk ruang-ruang publik untuk interaksi sosial berpengaruh, adalah determinan kualitas tempat yang sangat penting bagi peningkatan kapabilitas dan kebahagiaan masyarakat.

\section{DISKUSI DAN KESIMPULAN}

Penelitian menunjukkan bahwa elemen fisik sebagai pembentuk aset tempat mempengaruhi pembentukan aset lain yang berupa aset non fisik. Elemen-elemen fisik pembentuk kualitas tempat yang didapat dalam penelitian dapat dikelompokkan dalam 2 area objek perencanaan/perancangan ruang, yaitu struktur ruang dan kualitas urban fabric. Dikaitkan dengan temuan (Marans R.W. \& Stimson R., 2011), struktur ruang makro dalam bentuk sistem konsentrasi layanan kota dan jaringan penghubungnya mempengaruhi kapabilitas dan kebahagian melalui tingkat kemudahan dan efisiensi yang diberika. Sedangkan kualitas urban fabric berpengaruh melalui fasilitas relasi sosial. Penelitian ini memberikan contoh bahwa pendekatan subjektif seperti penggunaan kerangka survei kapabilitas yang merupakan alat bantu evaluasi diri secara perseptual oleh masyarakat terhadap lingkungan hidup dan kehidupannya dapat menjadi perangkat dasar evaluasi kualitas tempat yang akhirnya berkontribusi bagi perencanan tata ruang yang berorientasi pada kesejahteraan dan kebahagiaan. Pemakaian perangkat ini dapat mendukung gagasan (Ramadier, 2017; Ramadier \& Enaux, 2016) yang mempertimbangkan bahwa kebahagiaan dalam beberapa cara dapat dicapai memalui perrencanan elemen kualitas tempat yang terpahami melalui survey persepsi.

Pemahaman yang diperoleh dari penelitian memberi rekomendasi kepada 2 area intervensi perencanaan/perancangan kota berupa struktur ruang dan kualitas urban fabric. Perencanaan struktur ruang adalah gambaran 2 dimensi dari intervensi perencanaan, sedangkan perencanaan/perancangan urban fabric adalah intervensi bentuk 3 dimensi ruang hunian. Perencanan struktur ruang berfokus pada pembentukan sistem makro dan meso kota, sedangkan perancangan urban fabric adalah upaya membentuk keterlingkupan ruang-ruang dalam skala ketetanggaan (neighborhood space enclosure).

Dikembalikan pada konsep aset dalam pendekatan kapabilitas (Pramono, 2018), struktur ruang adalah tatanan (pengorganisasian) elemen-elemen fisik berupa penempatan/distribusi fasilitas umum kaitannya dengan agregasi perumahan serta tatanan jaringan transportasi dan utilitas. Tatanan 2 dimensional secara makro ini harus dapat memproduksi/mereproduksi aset institusional ekonomi (EIA) yang kemanfaatannya adalah meningkatkan kemudahan dalam memperoleh kebutuhan terutama komoditas fisikekonomi. Sedangkan rancangan urban fabric diarahkan untuk dapat menciptakan ruangruang publik yang nyaman untuk berinteraski sosial. Ruang-ruang fisik yang pada umumnya berfungsi sebagai pusat aktivitas sosial ini harus mampu memfasilitasi produksi/reproduksi aset institusi sosial (SIA).

Tata guna lahan area perencanaan yang pada umumnya menjadi diskusi penting dalam perencanaan kota, tidak terlalu menjadi perhatian para responden dari penelitian ini. Padahal sebenarnya dalam pertanyaan terbuka juga telah ada pertanyaan mengenai apa yang seharusnya dekat atau jauh agar tempat tinggal responden nyaman. Namun mungkin karena pada seluruh desa kasus dominasi guna lahannya adalah campuran (mixed use) dan tidak ditemukan fungsi-fungsi yang pada umumnya dapat mengganggu perumahan seperti industri besar atau seperti tempat pembuangan akhir sampah, maka guna lahan tidak menjadi isu. Sehingga hampir tidak ada responden yang menyebutkan jauhnya terhadap guna lahan tertentu sebagai pengurang kualitas tempat tinggal mereka. 


\section{UCAPAN TERIMA KASIH}

Terimakasih kepada Departemen Teknik Arsitektur dan Perencanaan Universitas Gadjah Mada yang telah memberikan dana bagi terselenggaranya penelitian ini pada tahun 2017.

\section{DAFTAR PUSTAKA}

BPS DIY. (2017). Indeks Kebahagiaan Daerah Istimewa Yogyakarta Tahun 2017 Sebesar 72,93. Retrieved from https://yogyakarta.bps.go.id/pressrelease/2017/09/04/812/indeks-kebahagiaan-daerah-istimewayogyakarta-tahun-2017-sebesar-72-93.html

Cloutier S., \& Pfeiffer D. (2017). Happiness: An Alternative Objective for Sustainable Community Development. In International Handbooks of Quality-of-Life (pp 85-96) (Phillips R., Wong C. (eds) Handbook of Community Well-Being Research). Dordrecht: Springer. Retrieved from https://doi.org/10.1007/97894-024-0878-2_5

DPPKA DIY. (n.d.). Peta Wilayah Administrasi DIY [Government]. Retrieved from http://dppka.jogjaprov.go.id/upload/files/peta_wil_adm_diy.jpg

Fleury-Bahi, G., Pol, E., \& Navarro, O. (2017). Introduction: Environmental Psychology and Quality of Life. In G. Fleury-Bahi, E. Pol, \& O. Navarro (Eds.), Handbook of Environmental Psychology and Quality of Life Research (pp. 1-8). Cham: Springer International Publishing. https://doi.org/10.1007/978-3-31931416-7_1

Hair, J. F. (1998). Multivariate Data Analysis. Prentice Hall.

Hair, J.F., Black, W.C., Babin, B.J., \& Anderson, R.E. (2010). Multivariate Data Analysis (7th Eds). Prentice Hall.

Heřmanová, E. (2012). Kvalita života a její modely v současném sociálním výzkumu (Quality of Life and its Models in Contemporary Social Research. Praha: Sociológia.

Ira V. (2003). Changing intra-urban structure of Bratislava city and its perception. Geografický Časopis, (55), 91-107.

Johnson, Richard A., \& Wichern, Dean W. (2013). Applied Multivariate Statistical Analysis (6th ed.). Pearson Education Limited.

Marans R.W., \& Stimson R. (2011). An Overview of Quality of Urban Life. In Marans R., Stimson R. (eds) Investigating Quality of Urban Life. Social Indicators Research Series (Vol. 45, pp. 1-29). Dordrecht: Springer. Retrieved from https://doi.org/10.1007/978-94-007-1742-8_1

Pramono, R. (2018). The transect of happiness and community's capability in urbanizing Yogyakarta. IOP Conference Series: Earth and Environmental Science, 126, 012099. https://doi.org/10.1088/17551315/126/1/012099

Pramono, R. W. D. (2016). Capability Approach for well-being Evaluation in Regional Development Planning: Case Study in Magelang Regency. Central Java, Indonesia [Yogyakarta]: Universitas Gadjah Mada. University of Groningen. Retrieved from https://www.rug.nl/research/portal/publications/capabilityapproach-for-wellbeing-evaluation-in-regional-development-planning(5154dbc9-00d1-41a2-b2d4a16e6cc62f8d).html

Pramono, R. W. D., \& Woltjer, J. (2011). Wellbeing and a Capability Approach in Planning Evaluation and Regional Development. In A. Hull, E. Alexander, A. Khakee, \& J. Woltjer (Eds.), Evaluation for Sustainability and Participation in Planning. London: Routledge.

Ramadier, T. (2017). Adjustment to Geographical Space and Psychological Well-Being. In G. Fleury-Bahi, E. Pol, \& O. Navarro (Eds.), Handbook of Environmental Psychology and Quality of Life Research (pp. 291-307). Cham: Springer International Publishing. https://doi.org/10.1007/978-3-319-31416-7_16

Ramadier, T., \& Enaux, C. (2016). Socio-Cognitive Accessibility to Places. In P. Frankhauser \& D. Ansel (Eds.), Deciding Where to Live (pp. 71-91). Wiesbaden: Springer Fachmedien Wiesbaden. https://doi.org/10.1007/978-3-658-15542-1_3

Rogerson, R. J., Findlay, A. M., Morris, A. S., \& Coombes, M. G. (1989). Indicators of Quality of Life: Some Methodological Issues. Environment and Planning A, 21(12), 1655-1666. https://doi.org/10.1068/a211655

Rummel, R. J. (1970). Applied Factor Analysis. United States of America: Northwestern University Press.

Santosa, S. (2002). SPSS Statistik Multivariat. Jakarta: Elex Media Komputindo.

Scannell, L., \& Gifford, R. (2017). The experienced psychological benefits of place attachment. Journal of Environmental Psychology, 51, 256-269. https://doi.org/10.1016/j.jenvp.2017.04.001 
Sen, A. (1999). Development as Freedom. New York: Anchor Books.

Sen, A. (2000). Social Exlusion: Concept, Application, and Scrutiny. Manila, Philippines: Office of Environment and Social Development, Asian Development Bank.

UN-United Nations. (2012). "A new economic paradigm is needed to capture social, economic and environmental aspects of sustainable development." Statement of the Secretary-General at the HighLevel Meeting on Well-being and Happiness, 2 April 2012, UN headquarters in New York.

van Kamp, I., Leidelmeijer, K., Marsman, G., \& de Hollander, A. (2003). Urban environmental quality and human well-being. Landscape and Urban Planning, 65(1-2), 5-18. https://doi.org/10.1016/S01692046(02)00232-3

Widarjono, A. (2010). Analisis Statistika Multivariat Terapan. Yogyakarta: UPP STIM YKPN. 